\title{
Front Matter: Volume 11808
}

, "Front Matter: Volume 11808," Proc. SPIE 11808, Organic and Hybrid Light Emitting Materials and Devices XXV, 1180801 (17 August 2021); doi: $10.1117 / 12.2606656$

SPIE Event: SPIE Organic Photonics + Electronics, 2021, San Diego, California, SPIE. United States 


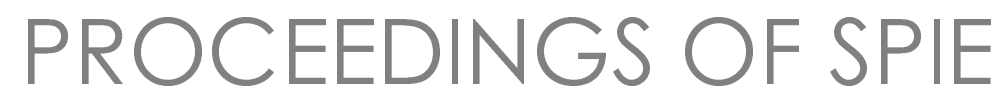

\title{
Organic and Hybrid Light Emitting Materials and Devices XXV
}

\author{
Chihaya Adachi \\ Tae-Woo Lee \\ Franky So \\ Editors
}

1-5 August 2021

San Diego, California, United States

Sponsored and Published by

SPIE 
The papers in this volume were part of the technical conference cited on the cover and title page. Papers were selected and subject to review by the editors and conference program committee. Some conference presentations may not be available for publication. Additional papers and presentation recordings may be available online in the SPIE Digital Library at SPIEDigitalLibrary.org.

The papers reflect the work and thoughts of the authors and are published herein as submitted. The publisher is not responsible for the validity of the information or for any outcomes resulting from reliance thereon.

Please use the following format to cite material from these proceedings:

Author(s), "Title of Paper," in Organic and Hybrid Light Emitting Materials and Devices XXV, edited by Chihaya Adachi, Tae-Woo Lee, Franky So, Proc. of SPIE 11808, Seven-digit Article CID Number (DD/MM/YYYY); (DOI URL).

ISSN: 0277-786X

ISSN: 1996-756X (electronic)

ISBN: 9781510644540

ISBN: 9781510644557 (electronic)

Published by

SPIE

P.O. Box 10, Bellingham, Washington 98227-0010 USA

Telephone +1 3606763290 (Pacific Time)

SPIE.org

Copyright @ 2021 Society of Photo-Optical Instrumentation Engineers (SPIE).

Copying of material in this book for internal or personal use, or for the internal or personal use of specific clients, beyond the fair use provisions granted by the U.S. Copyright Law is authorized by SPIE subject to payment of fees. To obtain permission to use and share articles in this volume, visit Copyright Clearance Center at copyright.com. Other copying for republication, resale, advertising or promotion, or any form of systematic or multiple reproduction of any material in this book is prohibited except with permission in writing from the publisher.

Printed in the United States of America by Curran Associates, Inc., under license from SPIE.

Publication of record for individual papers is online in the SPIE Digital Library.

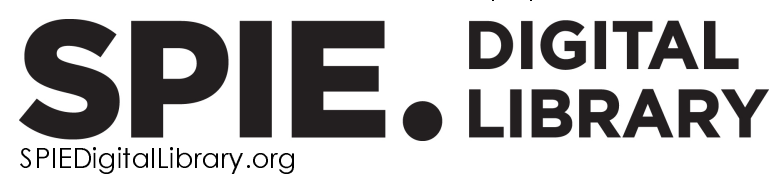

Paper Numbering: A unique citation identifier (CID) number is assigned to each article in the Proceedings of SPIE at the time of publication. Utilization of CIDs allows articles to be fully citable as soon as they are published online, and connects the same identifier to all online and print versions of the publication. SPIE uses a seven-digit CID article numbering system structured as follows:

- The first five digits correspond to the SPIE volume number.

- The last two digits indicate publication order within the volume using a Base 36 numbering system employing both numerals and letters. These two-number sets start with 00, 01, 02, 03, 04, $05,06,07,08,09,0 A, 0 B \ldots$ OZ, followed by 10-1Z, 20-2Z, etc. The CID Number appears on each page of the manuscript. 


\section{Contents}

DEVICE PHYSICS AND PROCESSING FOR OLEDS

$11808 \mathrm{OB} \quad$ A guide to qualitative haze measurements demonstrated on inkjet-printed silver electrodes for flexible OLEDs [1 1808-5]

11808 OG Improvement in the stability of phosphorescent OLED with solution-coated hole-transport layer via exciplex-triplet energy transfer [11808-13]

CHEMISTRY AND PHYSICS OF ORGANIC EMITTING MATERIALS

11808 OS Accelerated design and optimization of novel OLED materials via active learning [1 1808-25]

ORGANIC AND HYBRID PEROVSKITE DEVICES FOR BLUE EMISSION

11808 OW Stable pure-blue hyperfluorescence OLEDs (Invited Paper) [1 1808-28]

DEVICE PHYSICS AND ENGINEERING OF PEROVSKITE LIGHT-EMITING DIODES

$118080 Z$ Interfacial modification for high performance photodetector based on perovskite (Invited Paper) [1 1808-40]

1180817 Phase stabilization for high-performance perovskite light-emitting diodes (Invited Paper) [1 1808-39]

PEROVSKITE AND INORGANIC COLLOIDAL QUANTUM DOTS FOR LIGHT-EMITING DIODES

$1180811 \quad$ The influence of charge carriers in the hole transport layer on stability of quantum dot lightemitting devices [1 1808-51] 
Proc. of SPIE Vol. 11808 1180801-4

\section{Downloaded From: https://www.spiedigitallibrary.org/conference-proceedings-of-spie on 25 Apr 2023
Terms of Use: https://www.spiedigitallibrary.org/terms-of-use}

